\title{
Efficiency Gain in Plated Bifacial n-Type PERT Cells by Means of a Selective Emitter Approach Using Selective Epitaxy
}

María Recamán Payo a,, Yuandong Li $^{\mathrm{a}}$, Richard Russella, Sukhvinder Singha, Izabela Kuzma Filipekª Filip Duerinckx ${ }^{a}$, Jozef Szlufcik ${ }^{a}$ and Jef Poortmans ${ }^{a, b, c}$

\author{
a imec, Kapeldreef 75, B-300I Leuven, Belgium \\ ${ }^{b}$ Department of Electrical Engineering, KU Leuven, Kasteelpark, Arenberg 10, B-300I Leuven, Belgium \\ c Institute for Materials Research, UHasselt, Agoralaan, Gebouw D, B-3590 Diepenbeek, Belgium
}

\section{Highlights (5 points - 85 characters max including spaces)}

- Selective growth of doped regions by epitaxy on laser ablated textured surfaces.

- Metallization by simultaneous plating of $n$ - and $p$-type contacts in bifacial cells.

- $\quad$ Reduced $J_{0, \text { plated }}$ for $p$-type contacts by doping profile engineering with epitaxy.

- Thermal $\mathrm{SiO}_{2} / \mathrm{PECVD} \mathrm{SiN}_{\mathrm{x}}$ passivation after epitaxy at the same level than $\mathrm{ALD} \mathrm{Al}_{2} \mathrm{O}_{3}$.

- Gain in FF and $V_{\text {oc }}$ for bifacial cells with a selective epitaxial emitter approach.

\begin{abstract}
This work evaluates the potential of selective epitaxy to mitigate the recombination losses at the p-type contact regions of plated bifacial n-type PERT cells. Following the growth of a $500 \mathrm{~nm}, 2.5 \cdot 10^{19} \mathrm{~cm}^{-3}$ boron doped epitaxial layer at the emitter contact regions defined by laser ablation of the passivating dielectrics, both an increase in $\mathrm{V}_{\mathrm{oc}}(+6 \mathrm{mV})$ and $\mathrm{FF}(+1 \%$ absolute) are measured in the final cells compared to the reference with a homogeneous diffused emitter. These results come with an average efficiency gain of 0.3 and $0.5 \%$ absolute for front and rear side illumination, respectively. If the diffused, blanket emitter in the passivated regions is replaced by a thicker, lowly doped epitaxial profile $\left(3 \mu \mathrm{m}, 5 \cdot 10^{18} \mathrm{~cm}^{-3}\right)$ to further reduce recombination, an additional rise in implied $V_{o c}$ after metallization of $10 \mathrm{mV}$ is estimated. This increase would be the result of a reduction in $J_{0, \text { pass,emitter }}\left(\right.$ down to $6 \mathrm{fA} / \mathrm{cm}^{2}$ ) and $J_{0, \text { plated,emitter }}\left(\right.$ down to $1967 \mathrm{fA} / \mathrm{cm}^{2}$ ).
\end{abstract}

\section{Keywords}

Selective epitaxy, plating, bifacial solar cell, passivating contact, p-type contact.

\section{INTRODUCTION}

The bifacial PERT (Passivated Emitter, Rear Totally diffused) solar cells with the layout presented in Fig. I (left), and metallized using simultaneous plating of both n-type and p-type contacts, have already reached average efficiency values above $22 \%$ [I]. Nonetheless, a breakdown analysis of the recombination losses reveals that there is still an important contribution of $\mathrm{J}_{0 \text {,plated }}\left(\mathrm{J}_{0}\right.$ being the dark saturation current density at an injection level of $\left.10^{16} \mathrm{~cm}^{-3}\right)$ on both p-type diffused emitter $\left(\sim 4000 \mathrm{fA} / \mathrm{cm}^{2}\right)$ and n-type laser-doped BSF $\left(\sim 1300 \mathrm{fA} / \mathrm{cm}^{2}\right)$ contacts.

\footnotetext{
I Corresponding author: recaman@imec.be, Maria.RecamanPayo@gmail.com
} 

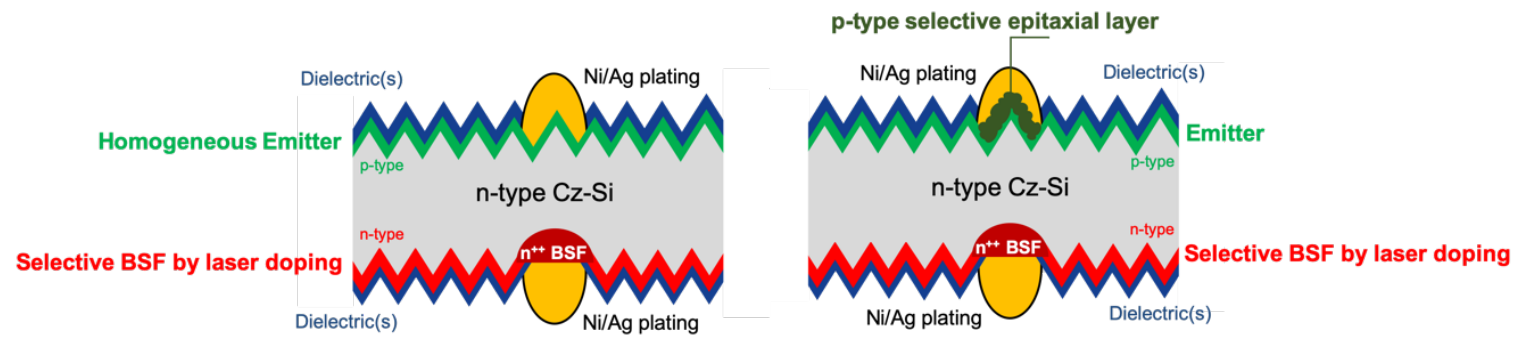

FIG. I. Layout of the bifacial PERT solar cells of this work with co-plated n-type and p-type contacts: (left) reference cell with homogeneous emitter, (right) " $\mathrm{p}^{+}$epi" cell with a selective emitter by selective epitaxy.

The recombination losses in the contact regions of these bifacial devices, with a metal contact fraction of approximately I \% for each contact polarity, account for more than $60 \%$ of the total recombination losses. These losses are currently the main factor limiting the open circuit voltage $\left(\mathrm{V}_{o c}\right)$ and, therefore, the solar cell efficiency within reach for these devices.

A lot of the present research to mitigate the recombination losses at the semiconductor/metal interface of bulk crystalline silicon solar cells focuses on the implementation of polysilicon-based passivating contacts [210]. In this work, however, we aim at reducing the recombination attributed to the p-type emitter contact, which of both contacts contributes with the highest losses, by locally introducing in such a region a highly doped p-type epitaxial layer as schematically depicted in FIG. I (right).

As herein reported, the selective p-type epitaxial emitter approach, which only relies on high doping as a passivating mechanism, still results in higher minority carrier recombination losses than a p-type polysiliconbased contact. For the p-type polysilicon-based contact structure, where the interfacial oxide plays a key role in the passivation of the bulk silicon surface, Jo values between 4 and $630 \mathrm{fA} / \mathrm{cm}^{2}$ were measured depending on the specific process technology, test structure in use and characterization methodology [II-20].

Nevertheless, the selective p-type epitaxial emitter brings advantages in terms of integration simplicity as well as collection efficiency of majority carriers at the corresponding electrode. Only one additional step between patterning and metallization is required to selectively grow a local epitaxial layer on the regions to be contacted. In the selective epitaxial growth of silicon by thermal chemical vapor deposition (CVD), the growing layer is the result of a balance between the simultaneous silicon deposition from a silicon source (for example, $\mathrm{SiH}_{2} \mathrm{Cl}_{2}$ ), and the silicon etching from a chlorinated source (for example, $\mathrm{HCl}$ ) upon substrates where only part of the surface is "masked" with a dielectric (stack) while the rest of the surface is "free" of dielectric(s). As shown in FIG. 2, the overall result is the growth of a silicon epitaxial layer solely on the bare silicon surface where the dielectric was opened during a previous patterning step. The remaining surface of the dielectric (stack), which will be kept for passivation and optical purposes at cell level, functions as a "mask" preventing the deposition of the epitaxial layer on that area [2I-29]. An equivalent local polysilicon-based contact structure on the front side of a solar cell would require a more complex processing sequence [5]. In addition, the presence of the interfacial oxide would contribute to increase the specific contact resistance for the whole stack metal/polysilicon/oxide/absorber compared to the values measured for standard monocrystalline silicon contacts. For p-type polysilicon-based contacts, $\rho_{c}$ values between I and $14 \mathrm{~m} \Omega \mathrm{cm}^{2}$ were already reported [14, 16-19]. 

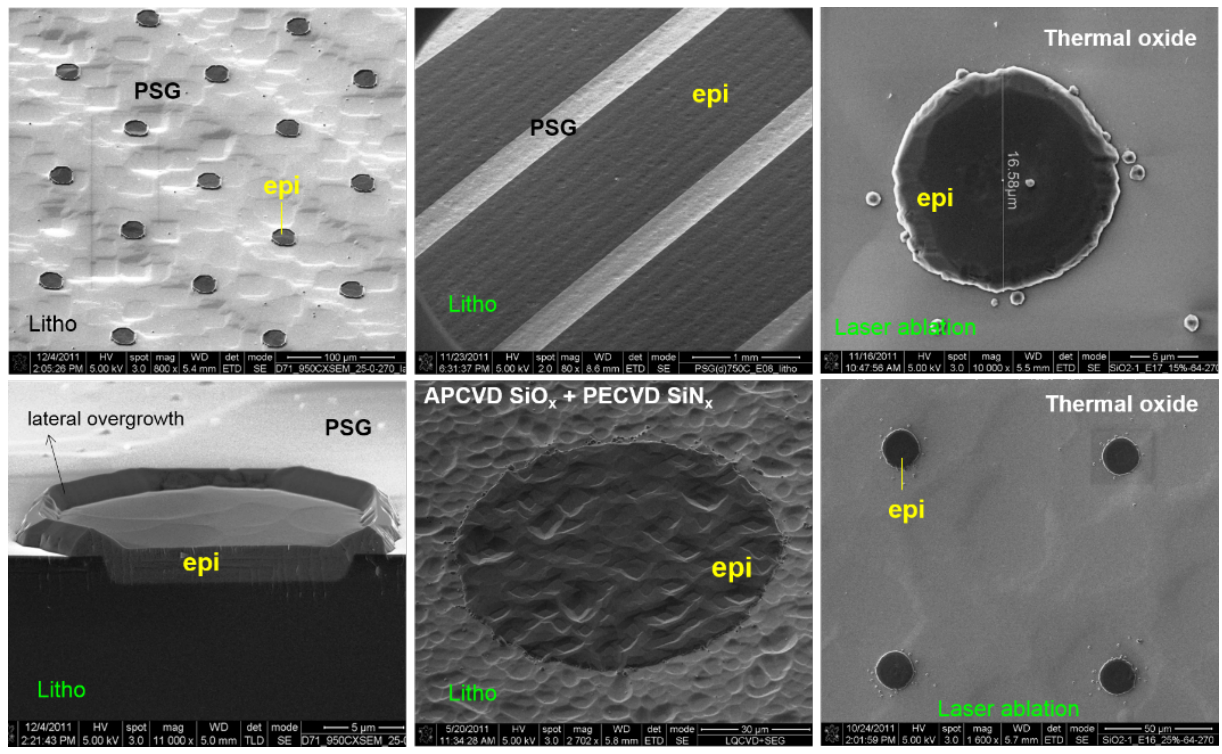

FIG. 2. SEM images illustrating examples of epitaxial layers selectively grown on silicon surfaces using a variety of dielectric masks patterned whether by laser ablation or photolithography.

The application of selective epitaxy to form the p-type local contact in bifacial PERT devices poses two main challenges: $(I)$ the feasibility to selectively grow an epitaxial layer on the silicon surface opened during the dielectric patterning by laser ablation, and (2) the impact of the epitaxial thermal budget on the passivating properties of both front and rear dielectrics. Selective epitaxy has been successfully applied on blanket sawdamage-etched and textured surfaces as well as surfaces patterned by photolithography [2I-29]. However, laser ablation of dielectrics to open the contact regions not only introduces damage, and therefore the presence of additional defects [30], but also gives rise to a very rough surface morphology as shown in FIG. 6 (left) which is not ideal for the growth of an epitaxial layer. Besides, dielectrics such as $A L D \mathrm{Al}_{2} \mathrm{O}_{3}$ and PECVD SiN $\mathrm{N}_{\mathrm{x}}$ are sensitive to a high thermal budget, and the growth of the epitaxial layer can degrade their passivating properties as a consequence of an increase in interface trap density, hydrogen effusion from the films, crystallization or other forms of chemical, physical and structural damage [3I-34].

Taking the previous remarks into consideration, the first part of this work addresses the development of a p-type selective epitaxial deposition process on laser ablated surfaces, which is also compatible with the dielectric stack used for passivation. The second part of this work focuses on the integration of the p-type epitaxial layer in the emitter contact regions of plated bifacial n-type PERT solar cells.

\section{MATERIALS AND METHODS}

\section{I p-Type epitaxy for the emitter contact regions}

Semi-device structures mimicking a bifacial PERT solar cell were fabricated to study the impact on passivation of the laser ablation process, the epitaxial thermal budget and the co-plating process. Those test structures, schematically depicted in FIG. 3, were fabricated on standard n-type monocrystalline Czochralski (Cz) silicon

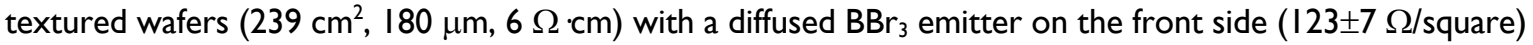
and a back surface field (BSF) by $\mathrm{POCl}_{3}$ diffusion at the rear side. Each diffusion process was realized using an approximately $100 \mathrm{~nm}$ thick PECVD $\mathrm{SiO}_{x}$ mask on one side to get single side doping and preserve the fully textured surface on both sides of the final structure. A deep $(3 \mu \mathrm{m})$ and lowly doped $\left(5 \cdot 10^{18} \mathrm{~cm}^{-3}\right)$ homogeneous (single-side) p-type epitaxial emitter (I $8 \pm 5 \Omega /$ square) was also alternatively used instead of the $\mathrm{BBr}_{3}$ emitter when assessing the recombination losses after plating at the emitter contacts.

As shown in FIG. 3 (left), two alternative dielectrics stacks were investigated as potential candidates for the emitter passivation: (a) the stack thermal $\mathrm{SiO}_{2} /$ PECVD SiN ${ }_{x}$ and, (b) the stack $A L D \mathrm{Al}_{2} \mathrm{O}_{3} /$ PECVD SiO $/$ /PECVD $\mathrm{SiN}_{x}$. 


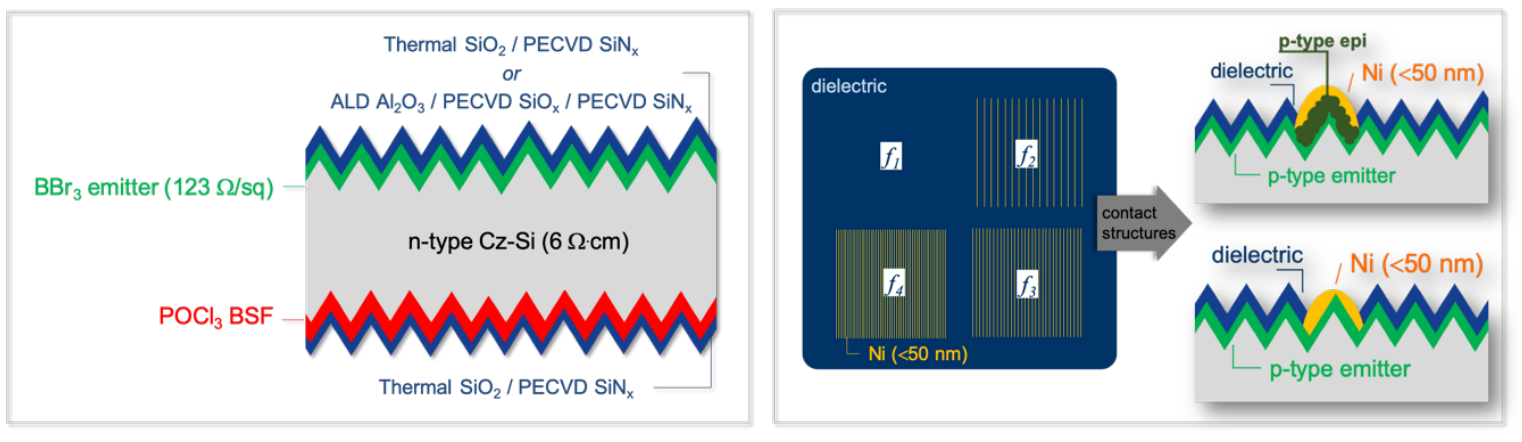

FIG. 3. Schematic of the structures employed to accomplish the growth of a p-type selective epitaxial layer on the laser ablated surface at the emitter contact regions: (left) test structure used to assess the impact of the epitaxial thermal budget on the dielectric passivation, and (right) test structure used to assess the p-type emitter contact recombination after plating where $f_{i}$ (between $0 \%$ and $10 \%$ ) represents the dielectric open fraction after laser ablation.

The dielectric patterning on the emitter side was performed by picosecond laser ablation using the Talisker ${ }^{\mathrm{TM}}$ ultraviolet $(355 \mathrm{~nm})$ laser of the Aethon Laser Platform from Coherent. The laser ablation was performed with a fixed laser repetition rate of $200 \mathrm{kHz}$, a laser fluence in the range $45-90 \mu / \mathrm{cm}^{2}$ and a scribing speed between $500-1000 \mathrm{~mm} / \mathrm{s}$. The ablation conditions were such that they guaranteed the opening of the dielectric stack with a minimum laser-induced damage.

The p-type epitaxial layers were grown in-house by CVD at reduced pressure ( $<100$ Torr) in an ASM EPSILON $\otimes 2000$ reactor, a single-wafer batch tool typically used for micro-electronics applications. The deposition took place in $\mathrm{H}_{2}$ atmosphere using $\mathrm{SiH}_{2} \mathrm{Cl}_{2}$ as silicon precursor. The doping of the layers was realized in-situ by means of $\mathrm{B}_{2} \mathrm{H}_{6}$ and, to keep selectivity, $\mathrm{HCl}$ was also employed as an etching source. The basic steps of this process consist of: (a) temperature ramp-up from $200^{\circ} \mathrm{C}$ to deposition temperature, (b) $\mathrm{H}_{2}$ bake, (c) selective silicon deposition, and (d) cool-down from deposition temperature to $200^{\circ} \mathrm{C}$. The $\mathrm{H}_{2}$ bake, taking place before the actual deposition step and at the same temperature, is a critical step which assists in the growth of a high-quality epitaxial layer by removing the native oxide from the silicon surface through hydrogen reduction.

To investigate the impact of the epitaxial thermal budget on the dielectrics' passivation, the structures depicted in FIG. 3 (left) have gone through the epitaxial step in the CVD reactor but without actual growth occurring, that is, in $\mathrm{H}_{2}$ atmosphere but without silicon and p-type dopant precursors.

The metallization of the contacts was realized by $\mathrm{Ni} / \mathrm{Ag}$ electroless and immersion plating. This process, which enables simultaneous, contact free, co-plating of $n$-type and $\mathrm{p}$-type contacts, has been specially developed for bifacial cells in combination with multi-wire interconnection technology [I, 35]. In this work, the standard plating conditions for monocrystalline silicon contacts described elsewhere [I] were applied.

The $\mathrm{J}_{0, \text { pass }}\left(\mathrm{J}_{0}\right.$ for the passivated regions) values herein reported were calculated at an injection level of $10^{16}$ $\mathrm{cm}^{-3}$ using Kane and Swanson approach [36] to fit the injection-level-dependent effective lifetime data measured by PL-QSSPC (Photo-Luminescence Quasi-Steady-State-Photoconductance) at $25^{\circ} \mathrm{C}$ in the LIS-R I multipurpose characterization tool from BT Imaging. In this analysis the parametrization for the intrinsic recombination in crystalline silicon by Richter et al. [37] was implemented. The $J_{0 . p l a t e d}\left(J_{0}\right.$ for the regions metallized using Ni/Ag co-plating) was extracted at an injection level of $10^{16} \mathrm{~cm}^{-3}$ following the method after Deckers et al. [38-39] on dedicated test structures, as shown in FIG. 3 (right), with a variable open fraction after laser ablation patterning, $f$, between $0 \%$ and $10 \%$. For each structure with a specific $f$, the injectionlevel-dependent effective lifetime was measured by PL-QSSPC. The difference between the saturation current density at the plated junctions and the saturation current density at the passivated junctions $\left(\mathrm{J}_{0, \text { plated }}-J_{0}\right.$,pass $)$ was extracted from the slope of the inverse effective lifetime at an injection level of $10^{16} \mathrm{~cm}^{-3}$ versus $f$. In the structures investigated where the recombination at the passivated surface dominates bulk recombination, $J_{0, \text { pass }}$ could be extracted from the intercept with the $f=0$ axis.

The specific contact resistance $\left(\rho_{c}\right)$ for the metal/semiconductor interface was measured on plated textured surfaces using the conventional transfer length method (TLM), originally proposed by Shockley et al. in 1964 [40] and extensively used and discussed in literature [4I-43]. In this work, the resistance measurements between progressing pairs of contacts as a function of the pair distance were performed in a $\mathrm{Kb}$.esi tool. 


\subsection{Solar cell integration}

Reference (Fig. I, left) and " $\mathrm{p}^{+}$epi" (Fig. I, right) plated bifacial n-type PERT solar cells were fabricated on textured n-type $\mathrm{Cz}$ silicon wafers $\left(239 \mathrm{~cm}^{2}, 180 \mu \mathrm{m}, 3.5 \Omega . \mathrm{cm}\right)$ using the process sequence depicted in FIG. 4. All the devices have a homogeneous $\mathrm{BBr}_{3}$ diffused emitter ( $130 \pm 2 \Omega /$ square) on the front side. However, unlike the reference, the " $\mathrm{p}^{+}$epi" cells also incorporate a local $2.5 \cdot 10^{19} \mathrm{~cm}^{-3}$ boron-doped, $500 \mathrm{~nm}$ thick epitaxial layer at the emitter contact regions. The emitter passivation stack for the " $\mathrm{p}+$ epi" cells consists of thermal $\mathrm{SiO}_{2} / \mathrm{PECVD} \mathrm{SiN} \mathrm{x}_{\mathrm{x}}$ while for the reference cells is based on $\mathrm{ALD} \mathrm{Al}_{2} \mathrm{O}_{3} / \mathrm{PECVD} \mathrm{SiO}_{\times} / \mathrm{PECVD} \mathrm{SiN}$.

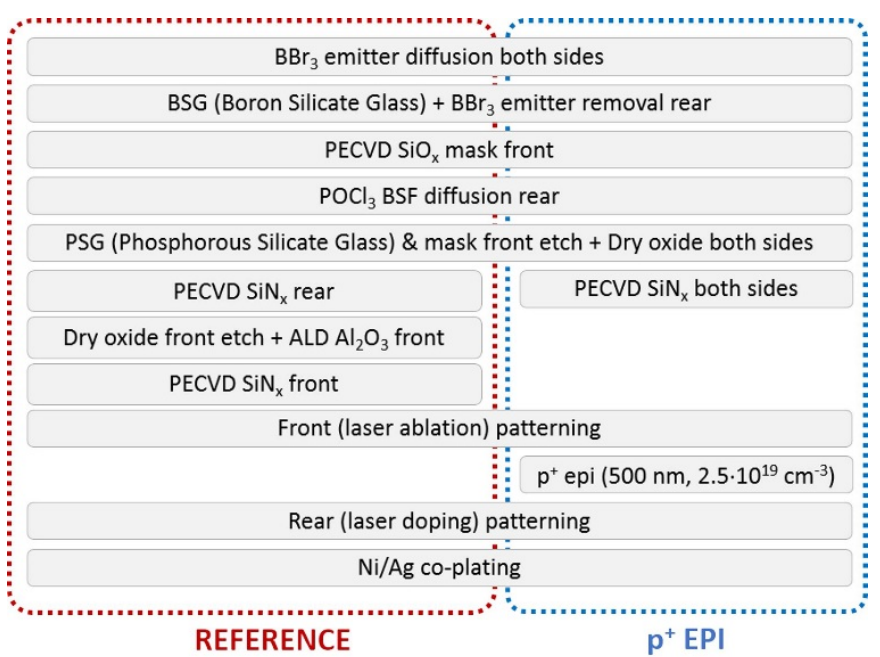

FIG. 4. Fabrication sequence for the reference and " $\mathrm{p}^{+}$epi" plated bifacial n-type PERT cells of this work.

The cells were characterized in-house by light I-V and dark I-V. These measurements were done in a solar simulator from Wacom Electric Co. using the Grid TOUCH contacting system developed by Pasan S.A. In these internal measurements the AMI.5G spectral irradiance was corrected based on a reference cell calibrated at Fraunhofer ISE CalLab.

\section{RESULTS AND DISCUSSION}

\section{I p-Type epitaxy for the emitter contact regions}

The first goal of this study was to assess the impact of the epitaxial thermal budget on the passivating properties of both front and rear dielectric stacks. With this in mind, the test structures schematically depicted in FIG. 3 (left) have gone through the epitaxial step, without actual growth occurring, to determine the maximum epitaxial temperature and (deposition) time that those dielectric layers could withstand without losing their passivating properties. The results are displayed in FIG. 5 in terms of $\mathrm{J}_{0 \text {,pass,total }}\left(\mathrm{J}_{0}\right.$,pass for the complete test structure) as a function of epitaxial temperature and (deposition) time for both emitter passivation approaches investigated: FIG. 5 (top) thermal $\mathrm{SiO}_{2} /$ PECVD $\mathrm{SiN}_{\mathrm{x}}$ and, FIG. 5 (bottom) ALD $\mathrm{Al}_{2} \mathrm{O}_{3} / \mathrm{PECVD} \mathrm{SiO}{ }_{x} / \mathrm{PECVD} \mathrm{SiN}_{\mathrm{x}}$. Those results are also compared to the values measured for the reference structure without epitaxial thermal budget, in other words, structures which would not include a p-type epitaxial layer at the emitter contact regions. 

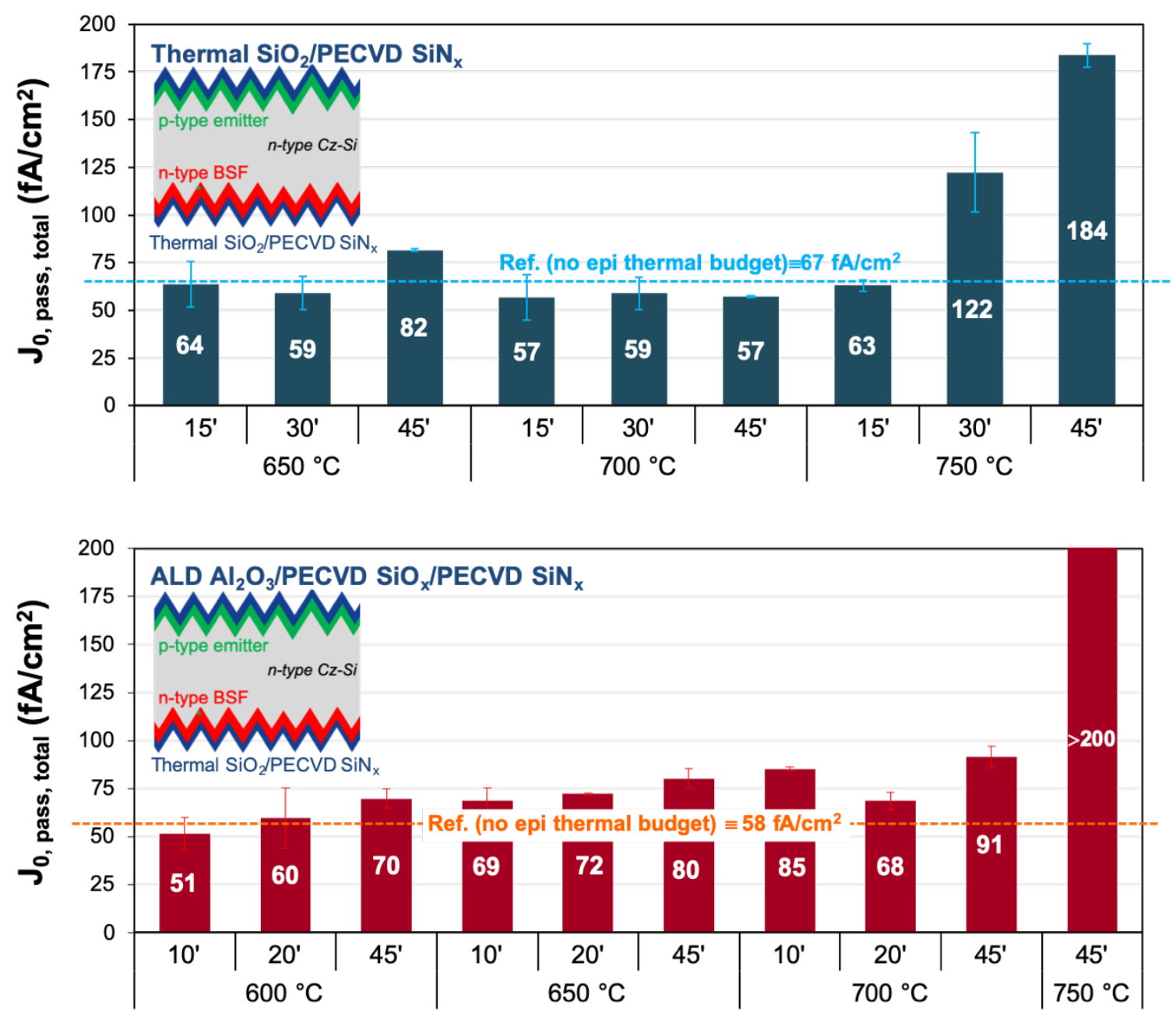

FIG. 5. J0,pass,total $\left(\mathrm{fA} / \mathrm{cm}^{2}\right.$ ) extracted at $10^{16} \mathrm{~cm}^{-3}$ (average of 3 samples/condition) for test structures after epitaxial thermal budget and for the reference (with no epitaxial step). Emitter passivation by: (top) thermal $\mathrm{SiO}_{2} / \mathrm{PECVD} \mathrm{SiN}_{\mathrm{x}}$, and (bottom) $\mathrm{ALD} \mathrm{Al}_{2} \mathrm{O}_{3} / \mathrm{PECVD} \mathrm{SiO}_{x} / \mathrm{PECVD} \mathrm{SiN} \times$.

When using thermal $\mathrm{SiO}_{2} / \mathrm{PECVD} \mathrm{SiN}_{\mathrm{x}}$, the results confirm that there is a remarkable increase in recombination after an epitaxial thermal budget above $750{ }^{\circ} \mathrm{C}(>30 \mathrm{~min})$. A similar study performed on symmetric BSF and emitter structures reveals that this degradation happens simultaneously for both the $\mathrm{p}$ type and the $n$-type doped regions for which there is a 3 -fold and a 6 -fold increase in $\int_{0, \text { pass, }}$, respectively, when the epitaxial step is performed at $750^{\circ} \mathrm{C}$ compared to the values measured at $700{ }^{\circ} \mathrm{C}\left(\mathrm{J}_{\text {o,pass, emitter }} \sim 47 \mathrm{fA} / \mathrm{cm}^{2}\right.$ $J_{0, \text { pass,BsF }} \sim 10 \mathrm{fA} / \mathrm{cm}^{2}$ at $700{ }^{\circ} \mathrm{C}$ ) [44]. In this case, an optimum epitaxial deposition temperature of $700{ }^{\circ} \mathrm{C}$ goes together with the suitable conditions to contribute with hydrogen passivation from PECVD $\mathrm{SiN}_{\mathrm{x}}$. Hydrogen is known to be released from this dielectric around that temperature [45-46].

The same investigation on the structures with $\mathrm{ALD} \mathrm{Al}_{2} \mathrm{O}_{3} / \mathrm{PECVD} \mathrm{SiO}_{x} / \mathrm{PECVD} \mathrm{SiN}_{\mathrm{x}}$ confirms that selective epitaxy would introduce a thermal budget which is too large to keep the excellent passivation measured for the reference case. Only if epitaxy took place at a temperature below $600^{\circ} \mathrm{C}$, we could not only keep but also improve the performance compared to the reference. At higher deposition temperature the passivation collapses because of different forms of damage (increase in interface trap density, hydrogen desorption from defects, stress or crystallization of the films) [3I-34]. When the experiment was realized on symmetric BSF and emitter structures, the results demonstrate that this passivation loss is mainly dominated by the quicker degradation of $A L D \mathrm{Al}_{2} \mathrm{O}_{3}$. The $\mathrm{J}_{0 \text {,pass,emitter }}$ for symmetric emitter structures passivated with $A L D$ $\mathrm{Al}_{2} \mathrm{O}_{3} / \mathrm{PECVD} \mathrm{SiO}{ }_{x} / \mathrm{PECVD} \mathrm{SiN} \mathrm{N}_{x}$ increases more than 10 times after an epitaxial step at $750^{\circ} \mathrm{C}$ compared to the values measured at $600^{\circ} \mathrm{C}\left(\mathrm{J}_{0, \text { pass,emitter }} \sim 27 \mathrm{fA} / \mathrm{cm}^{2}\right.$ at $\left.600{ }^{\circ} \mathrm{C}\right)$. 
In view of the previous results, the implementation of an epitaxially grown p-type layer at the emitter contact regions of bifacial PERT solar cells focused on the emitter passivation by thermal $\mathrm{SiO}_{2} / \mathrm{PECVD} \mathrm{SiN}_{\mathrm{x}}$, and on the development of a selective epitaxial process at $700{ }^{\circ} \mathrm{C}$. At this temperature there is a broad processing window for the (deposition) time (from 10 min up to 120 min tested in this work), for which the emitter passivation by thermal $\mathrm{SiO}_{2} / \mathrm{PECVD} \mathrm{SiN}_{\mathrm{x}}$ after epitaxial thermal budget is even at the same level than the ALD $\mathrm{Al}_{2} \mathrm{O}_{3}$-based emitter passivation.
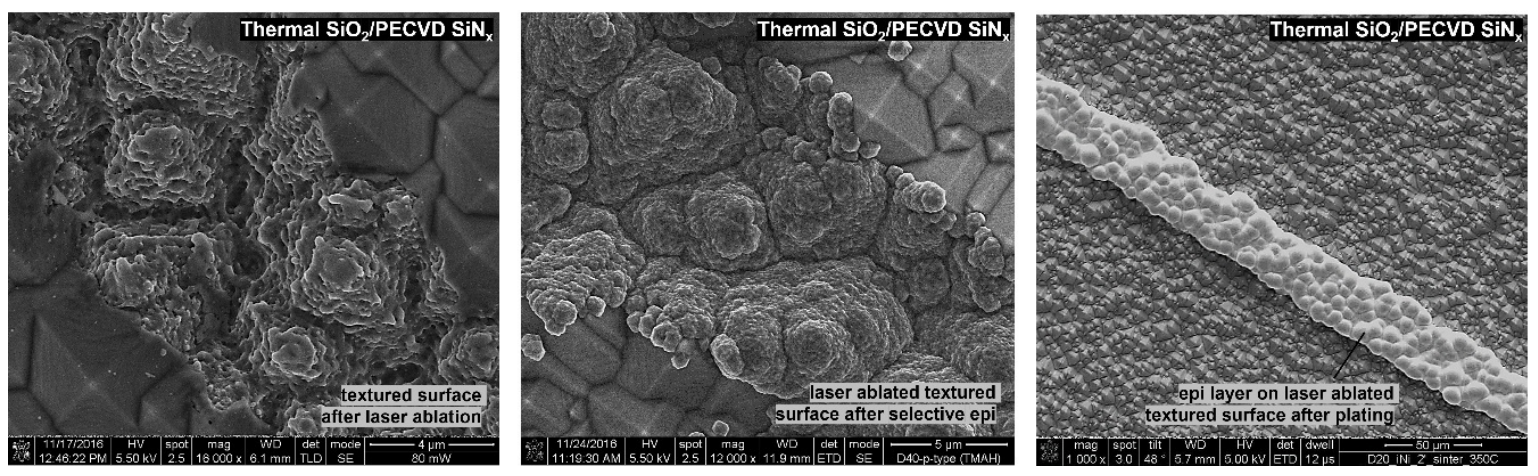

FIG. 6. Top view SEM images: (left) textured surface after laser ablation, (middle) laser ablated textured surface after the selective growth of a p-type epitaxial layer, and (right) p-type epitaxial layer selectively grown on a laser ablated textured surface after plating.

The following step in this development aimed at the patterning prior to epitaxy and the metallization of the grown layers. The thermal $\mathrm{SiO}_{2} / \mathrm{PECVD} \mathrm{SiN}_{\mathrm{x}}$ patterning was realized using the laser ablation conditions described in section 2.I where approximately $10 \mu \mathrm{m}$ wide lines were opened. The top view SEM image of FIG. 6 (left) shows the surface morphology of the laser ablated textured surface prior to epitaxy. As for any doping process, a cleaning step must be introduced between the laser ablation patterning of the dielectrics and the selective epitaxial step. The cleaning is required to remove any impurity or native oxide present on the open silicon surface, which can prevent a selective deposition or unnecessarily degrade the quality of the grown film and therefore its electronic properties. The iPV cleaning we normally use in-house during solar cell processing [47], and which consists of a 2-step sequence based on DIW/O $/ \mathrm{HCl}$ and DIW/HF/HCl was also applied here prior to epitaxy. The SEM image of FIG. 6 (middle) shows the surface morphology of a ptype epitaxial layer selectively grown on a laser ablated textured surface after the iPV cleaning. As shown in FIG. 6 (right), the plating of those layers was proven to be successful. The contact adhesion was tested to be as good as for the reference case without epitaxy, and the $\rho_{c}$ for an epitaxial layer of $2.5 \cdot 10^{19} \mathrm{~cm}^{-3}$ and 500 $750 \mathrm{~nm}$ was also at the same level as the reference $\left(1.6 \mathrm{~m} \Omega \mathrm{cm}^{2}\right)$. With respect to the recombination losses, FIG. 7 shows the $J_{0, \text { plated }}$ values which were measured after plating for the p-type emitter contacts herein investigated. The reference structure consisting of a plated, laser ablated $\mathrm{BBr}_{3}$ (I23 $\Omega /$ square) contact contributed with the highest recombination losses $\left(J_{0, \text { plated,reference }} 3994 \mathrm{fA} / \mathrm{cm}^{2}\right)$. The plated contact incorporating a $500 \mathrm{~nm}, 2.5 \cdot 10^{19} \mathrm{~cm}^{-3} \mathrm{P}$-type epitaxial layer between the metal and the laser ablated $\mathrm{BBr}_{3}\left(\mathrm{I}_{23}\right.$ $\Omega$ /square) emitter could enable a twenty-five percent reduction in the recombination losses $\left(\mathrm{J}_{0, \text { plated,epi/BBr3 }} \sim 3063 \mathrm{fA} / \mathrm{cm}^{2}\right)$ compared to the reference. If, in addition, the $\mathrm{BBr}_{3}$ diffused emitter (I $23 \Omega /$ square) was replaced by a deep $(3 \mu \mathrm{m})$ and lowly doped $\left(5 \cdot 10^{18} \mathrm{~cm}^{-3}\right)$ p-type epitaxial emitter (I I8 $\Omega /$ square), the recombination at the emitter contact regions would be even further reduced $\left(J_{0, \text { plated,epi/epi }} \sim 967 \mathrm{fA} / \mathrm{cm}^{2}\right)$ to half of the value measured for the reference contacts. 


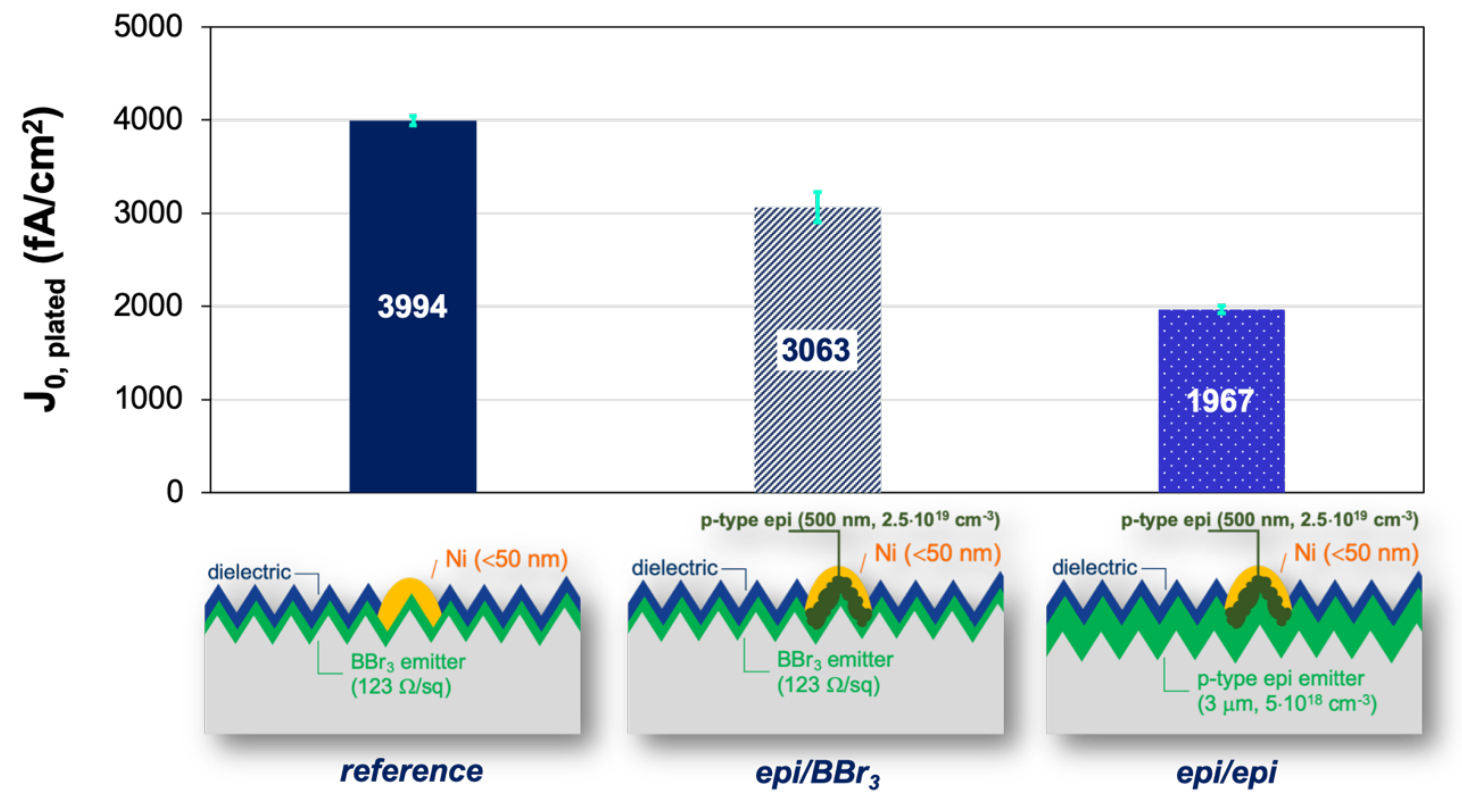

FIG. 7. J0,plated $\left(\mathrm{fA} / \mathrm{cm}^{2}\right)$ extracted at $10^{16} \mathrm{~cm}^{-3}$ (average of 4 samples/condition) for the three type of plated p-type emitter contacts investigated: reference, epi/BBr 3 and epi/epi.

These results align with the general trend already reported in literature [48-49] where the recombination losses for the metallized regions decrease with increasing surface dopant concentration and junction thickness. The p-type epitaxial layer locally grown at the emitter contact regions is more highly doped than the $\mathrm{BBr}_{3}$ diffused emitter. Secondary lon Mass Spectrometry (SIMS) confirmed that the p-type epitaxial contact layer has a uniform doping of $2.5 \cdot 10^{19} \mathrm{~cm}^{-3}$ through its whole thickness of $500 \mathrm{~nm}$, while the $\mathrm{BBr}_{3}$ diffused emitter underneath has a Gaussian profile with a surface concentration $\left(N_{s}\right)$ about $9 \cdot 10^{18} \mathrm{~cm}^{-3}$. The impact of the increase in junction thickness is especially remarkable for the case where the $\mathrm{BBr}_{3}$ diffused emitter $\left(<1 \mu \mathrm{m}, N_{s} \cong 9 \cdot 10^{18} \mathrm{~cm}^{-3}, 123 \pm 7 \Omega / \mathrm{square}\right)$ is replaced by the thicker and more lowly doped p-type epitaxial emitter $\left(3 \mu \mathrm{m}, 5 \cdot 10^{18} \mathrm{~cm}^{-3}\right.$, I $\left.18 \pm 5 \Omega / \mathrm{square}\right)$. Further reduction in $\mathrm{J}_{0, \text { plated,epiliBr3 }}$ or $\mathrm{J}_{0, \text { plated,epilepi }}$ could be expected if the selective epitaxial deposition process would be adapted to increase the doping level of the locally grown p-type epitaxial contact layer above the current value of $2.5 \cdot 10^{19} \mathrm{~cm}^{-3}$.

\subsection{Solar cell integration}

The results of TABLE I confirm the overall efficiency gain for the " $\mathrm{p}^{+}$epi" flow corresponding to an improvement in both $\mathrm{V}_{\mathrm{oc}}(+6 \mathrm{mV})$ and fill factor (FF) (+I \% absolute).

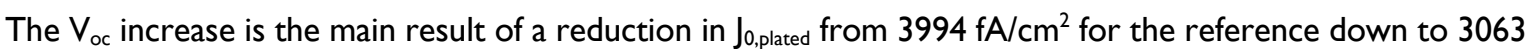
$\mathrm{fA} / \mathrm{cm}^{2}$ for the "p $\mathrm{p}^{+}$epi" group as previously presented in FIG. 7. The $\mathrm{J}_{0 \text {,pass }}$ for the $\mathrm{BBr}_{3}$ emitter $(130 \pm 2$ $\Omega /$ square) in the " $p$ " epi" flow with thermal $\mathrm{SiO}_{2} / P E C V D \mathrm{SiN}_{x}\left(2 \mathrm{I} \pm 3.5 \mathrm{fA} / \mathrm{cm}^{2}\right)$ was measured to be at the same level than the one measured for the reference flow with $\mathrm{ALD} \mathrm{Al}_{2} \mathrm{O}_{3} / \mathrm{PECVD} \mathrm{SiO}{ }_{x} / P E C V D \mathrm{SiN}_{x}\left(22 \pm 0.6 \mathrm{fA} / \mathrm{cm}^{2}\right)$.

Although the series resistance for both groups was in the same range $\left(0.5-0.6 \mathrm{~m} \Omega \cdot \mathrm{cm}^{2}\right)$, the shunt resistance for the " $\mathrm{p}^{+}$epi" cells was systematically larger $(>20 \Omega)$ than for the reference $(<10 \Omega)$. TABLE I also reports lower $\mathrm{J}_{02}$, which accounts for the recombination in the junctions, for the " $\mathrm{p}^{+}$epi" cells. The better values achieved for the shunt resistance as well as the J02 may explain the gain in FF for the " $\mathrm{p}^{+}$epi" flow. In turn, this improvement could be associated to the thickening of the emitter contact by the presence of the p-type epitaxial layer and, thereby, the mitigation of the patterning and metallization-induced damage compared to the reference group. 
TABLE I. Average (and standard deviation) I-V results for the reference and " $\mathrm{p}^{+}$epi" plated bifacial $\mathrm{n}$-type PERT cells of this work $\left(239 \mathrm{~cm}^{2}\right)$. In-house measurements.

\begin{tabular}{cccccccc}
\hline \hline Cell type & Illumination side & $\begin{array}{c}J_{s c} \\
\left(\mathrm{~mA} / \mathrm{cm}^{2}\right)\end{array}$ & $\begin{array}{c}V_{\text {oc }} \\
(\mathrm{mV})\end{array}$ & $\begin{array}{c}F F \\
(\%)\end{array}$ & $\begin{array}{c}\eta \\
(\%)\end{array}$ & $n$ & $\begin{array}{c}J_{02} \\
\left(10^{-9} \mathrm{~A} / \mathrm{cm}^{2}\right)\end{array}$ \\
\hline $\begin{array}{c}\text { Reference } \\
(8 \text { cells })\end{array}$ & Emitter & $40.4_{ \pm 0.0}$ & $673_{ \pm 1}$ & $79.5_{ \pm 0.6}$ & $21.6_{ \pm 0.2}$ & 1.12 & 11.7 \\
$\mathrm{P}^{+}$Epi & BSF & $38.5_{ \pm 0.4}$ & $672_{ \pm 2}$ & $79.2_{ \pm 0.6}$ & $20.5_{ \pm 0.2}$ & & \\
$(14$ cells $)$ & Emitter & $40.1_{ \pm 0.1}$ & $679_{ \pm 2}$ & $80.4_{ \pm 1.0}$ & $21.9 \pm 0.3$ & & 3.4 \\
\hline \hline
\end{tabular}

When the bifacial cells are illuminated from the rear side, the improvements in the " $\mathrm{P}^{+}$epi" flow correspond to an absolute efficiency gain of $0.5 \%$, while this one is limited to $0.3 \%$ absolute for front side illumination. The smaller efficiency gain in the latter case is because of a lower short circuit current density $\left(\mathrm{J}_{\text {sc }}\right)$ for the cells with a selective epitaxial emitter for which the emitter contact line width $(\sim 19 \mu \mathrm{m})$ is wider than for the reference $(\sim 15 \mu \mathrm{m})$. This increase in the line width is the consequence of the lateral overgrowth of the 500 $\mathrm{nm}$ epitaxial layer on the open dielectric region as depicted in FIG. 8. At cell level this $\int_{\mathrm{sc}}$ loss could be minimized by correcting the line pitch at the emitter contact without compromising the FF.
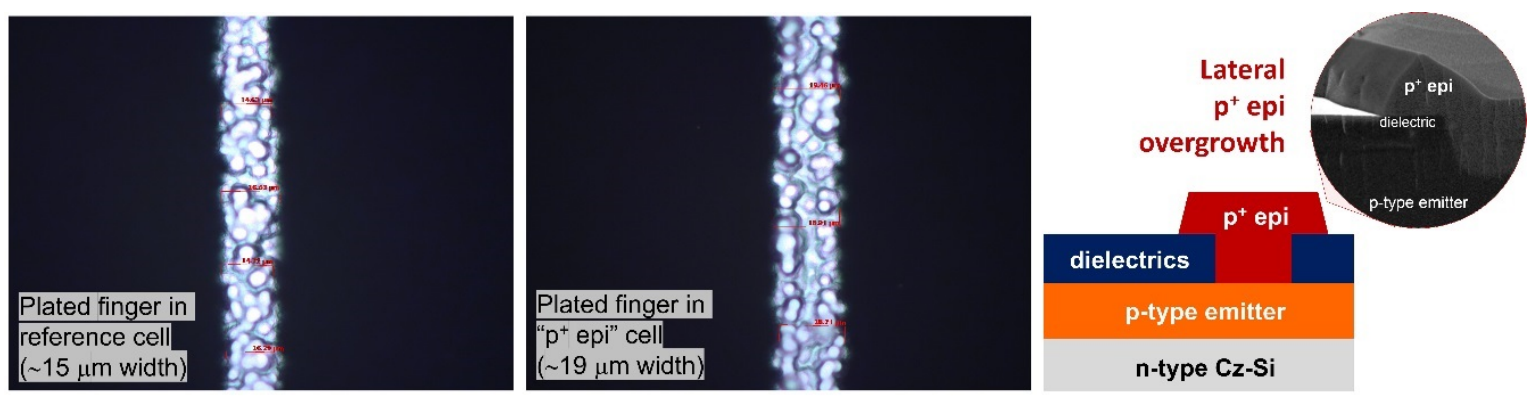

FIG. 8. (left) Optical microscope image of a plated finger in a reference cell, (middle) Optical microscope image of a plated finger in a " $\mathrm{p}^{+}$epi" cell, and (right) schematic of the lateral epitaxial overgrowth at the edge of the contact lines opened in the dielectric stack.

In this work, the best " $\mathrm{p}^{+}$epi" solar cell achieved a power conversion efficiency of $22.1 \%\left(\mathrm{~J}_{\mathrm{sc}}=40.1 \mathrm{~mA} / \mathrm{cm}^{2}\right.$, $V_{o c}=680 \mathrm{mV}$ and $\mathrm{FF}=81.0 \%$, in-house measurements for illumination from the emitter side). However, further improvements could still be realized, if we consider that the incorporation of the epitaxial layer in the contact regions enables an independent optimization of the passivated emitter profile from that one in the metallized areas. With this strategy in mind, for example, an increase in implied $\mathrm{V}_{\text {oc }}$ after metallization of at least $10 \mathrm{mV}$ could be estimated when replacing the $\mathrm{BBr}_{3}$ diffused emitter by the thick $(3 \mu \mathrm{m})$ and lowly doped $\left(5 \cdot 10^{18} \mathrm{~cm}^{-3}\right)$ p-type epitaxial emitter (I I8 $\pm 5 \Omega /$ square) already presented in section 2.2 . The gain in implied $V_{o c}$ would be the result of: $(a)$ a lower $J_{0, \text { pass,emitter }}=6 \pm I f A / \mathrm{cm}^{2}$ because of the significant reduction in Auger recombination, and $(b)$ a lower $J_{0, \text { plated,epi/epi }}=1967 \pm 42 \mathrm{fA} / \mathrm{cm}^{2}$ because of the thicker doped region under the metal contact.

\section{Acknowledgements}

The work in this paper was partially funded by Kuwait Foundation for the advancement of Sciences under project number PII5-I5EE-0I. 


\section{CONCLUSIONS}

This work demonstrates the feasibility of selective epitaxy to locally grow doped layers on laser ablated textured surfaces, and the potential of the technology to reduce the recombination losses at the $p$-type emitter contacts of bifacial plated n-type PERT solar cells. A selective epitaxial deposition process at $700^{\circ} \mathrm{C}$ and compatible with an emitter passivation by thermal $\mathrm{SiO}_{2}$ and/or PECVD layers was developed. By means of this process, and in I-single step between dielectric patterning by laser ablation and metallization by plating, a $500 \mathrm{~nm}, 5 \cdot 10^{18} \mathrm{~cm}^{-3} \mathrm{p}$-type epitaxial layer was locally grown at the emitter contacts. The bifacial devices with the locally grown p-type epitaxial layer demonstrated an average gain both in $\mathrm{V}_{\mathrm{oc}}(+6 \mathrm{mV})$ and $\mathrm{FF}(+\mathrm{I} \%$ absolute) compared to the reference without epitaxy, reaching a maximum solar cell efficiency of $22.1 \%$ (for illumination from the emitter side). This improvement is associated to the reduction in $\mathrm{J}_{0 . \text { plated }}$ for the epitaxial case. The $J_{0 \text {,plated }}$ for the reference structure consisting of a plated, laser ablated $\mathrm{BBr}_{3}(123 \Omega / \mathrm{square})$ contact was about $3994 \mathrm{fA} / \mathrm{cm}^{2}$ while for the contact additionally incorporating a $500 \mathrm{~nm}, 2.5 \cdot 10^{19} \mathrm{~cm}^{-3}$ p-type epitaxial layer was reduced to $3063 \mathrm{fA} / \mathrm{cm}^{2}$. Besides, if the $\mathrm{BBr}_{3}$ diffused emitter (I23 $\Omega /$ square) was replaced by a deep $(3 \mu \mathrm{m})$ and lowly doped $\left(5 \cdot 10^{18} \mathrm{~cm}^{-3}\right)$ p-type epitaxial emitter (II8 $\Omega /$ square), the $J_{0 \text {,plated }}$ would be even further reduced down to approximately $1967 \mathrm{fA} / \mathrm{cm}^{2}$ which, if integrated, could also contribute to a further improvement in the solar cell efficiency.

\section{REFERENCES}

[I] Russell, R. et al. Simultaneous fabrication of $\mathrm{n}$ \& $\mathrm{p}$ contacts for bifacial cells by a novel co-plating process. Proceedings of the $33^{\text {rd }}$ European Photovoltaic Solar Energy Conference and Exhibition, Amsterdam (The Netherlands) 2017, 2/2-217. Https://doi.org/I 0.4229/EUPVSEC20172017-2BP.I.3.

[2] Feldmann, F. Carrier-selective contacts for high-efficiency Si solar cells. Doctoral Dissertation, Universität Freiburg im Breisgau, 2015.

[3] Benick J. et al. High-efficiency n-type HP mc silicon solar cells. IEEE Journal of Photovoltaics 7(5) (2017) II7I-I I75. Https://doi.org/I 0.II09//PHOTOV.2017.27|4139.

[4] Feldmann, F. et al. Evaluation of TOPCon technology on large area solar cells. Proceedings of the $33^{\text {rd }}$ European Photovoltaic Solar Energy Conference and Exhibition, Amsterdam (The Netherlands) 2017, 465-467. Https://doi.org//0.4229/EUPVSEC20172017-2DO.3.3.

[5] Naber, R.C.G. et al. $\mathrm{BBr}_{3}$ emitter passivation by ultra-thin boron doped LPCVD polysilicon layers. Proceedings of the $33^{\text {rd }}$ European Photovoltaic Solar Energy Conference and Exhibition, Amsterdam (The Netherlands) 2017, 472-475. Https://doi.org/I0.4229/EUPVSEC201720I7-2DO.3.6.

[6] Peibst, R. et al. Industrial, screen-printed double-side contacted POLO cells. Proceedings of the $33^{\text {rd }}$ European Photovoltaic Solar Energy Conference and Exhibition, Amsterdam (The Netherlands) 2017, 45I-454. Https://doi/org/I0.4229/EUPVSEC20172017-2DO.2.2.

[7] Richter, A. et al. $n$-Type Si solar cells with passivating electron contact: Identifying sources for efficiency limitations by wafer thickness and resistivity variation. Solar Energy Conference Materials and Solar Cells 173 (2017) 96-105. Https://doi.org//0.1016/j.solmat.2017.05.042.

[8] Stodolny, M.K. et al. Material properties of LPCVD processed n-type poly-Si passivating contacts and application in PERpoly industrial bifacial solar cells. Energy Procedia 124 (2017) 635-642. Https://doi.org//0.1016/j.egypro.2017.09.250.

[9] Haase, F. et al. Laser contact openings for local poly-Si-metal contacts enabling 26.1\%-efficient POLOIBC solar cells. Solar Energy Conference Materials and Solar Cells I86 (2018) 184-193. https://doi.org//0.1016/j.solmat.2018.06.020.

[10] Melskens, J. et al. Passivating contacts for crystalline silicon solar cells: from concepts and materials to $\begin{array}{lllll}\text { prospects. IEEE Journal of Photovoltaics 8(2) (2018) 373-388. } & \end{array}$ Https://doi.org/I0.I 109/JPHOTOV.2018.2797/ 06.

[II] Romer, U. et al. Ion implantation for poly-Si passivated back-junction back-contacted solar cells. IEEE Journal of Photovoltaics 5(2) (2015) 507-5 I4. Https://doi.org/I0.II09/JPHOTOV.2014.2382975.

[12] Krügener, J. et al. Dopant diffusion from $\mathrm{p}^{+}$-poly-Si into c-Si during thermal annealing. Conference Record of the 43 ${ }^{\text {rd }}$ IEEE Photovoltaic Specialists Conference, Portland (USA) 2016, 245I-2454. Https://doi.org/10.1 109/PVSC.2016.7750083.

[13] Wu, Y. et al. In-situ doping and local overcompensation of high performance LPCVD polysilicon passivated contacts as approach to industrial IBC cells. Energy Procedia 92 (2016) 427-433. Https://doi.org//0.1016/j.egypro.2016.07.123.

[14] Yan, D. et al. Passivating contacts for silicon solar cells based on boron-diffused recrystallized amorphous silicon and thin dielectric interlayers. Solar Energy Conference Materials and Solar Cells I52 (2016) 73- 
79. Https://doi.org//0.1016/j.solmat.2016.03.033.

[15] Larionova, $Y$. et al. On the recombination behavior of $p^{+}$-type polysilicon on oxide junctions deposited by different methods on textured and planar surfaces. Physica Status Solidi A 214(8) (2017) 17000581/5. Https://doi.org/10.1002/pssa.201700058.

[16] Rienäcker, M. et al. Junction resistivity of carrier-selective polysilicon on oxide junctions and its impact on solar cell performance. IEEE Journal of Photovoltaics 7(I) (2017) II-I8. Https://doi.org/10.1109/JPHOTOV.2016.2614123.

[17] Çiftpınar, H.E. et al. Study of screen printed metallization for polysilicon based passivating contacts. Energy Procedia 124 (2017) 85I-86I. Https://doi.org//0.10I6/j.egypro.2017.09.242.

[18] Mack, S. et al. Screen-printed metallization for p-type poly-Si passivated contacts formed by LPCVD. Proceedings of the $33^{\text {rd }}$ European Photovoltaic Solar Energy Conference and Exhibition, Amsterdam (The Netherlands) 2017, 468-47I. Https:doi.org//0.4229/EUPVSEC20172017-2DO.3.5.

[19] Cuevas, A. et al. Silicon solar cells by "DESIJN" (Deposited Silicon Junctions). Proceedings of the $35^{\text {th }}$ European Photovoltaic Solar Energy Conference and Exhibition, Amsterdam (The Netherlands) 2018, 233-237. Https://doi.org//0.4229/35thEUPVSEC20182018-2BP.I.5.

[20] Young, D.L. et al. Front/back poly-Si/SiO 2 passivated contact device with $\mathrm{V}_{o c}>720 \mathrm{mV}$. Proceedings of the $35^{\text {th }}$ European Photovoltaic Solar Energy Conference and Exhibition, Amsterdam (The Netherlands) 2018, 700-703. Https://doi.org/10.4229/35thEUPVSEC20182018-2AV.3.32.

[2I] Recamán Payo, M. et al. Method for forming patterns of differently doped regions. Patent WO $2013 / 020868 \mathrm{Al}$.

[22] Recamán Payo, M. et al. Boron-doped selective silicon epitaxy: high efficiency and process simplification in interdigitated back contact cells. Progress in Photovoltaics Research and Applications 22(7) (2014) 7I I-725. Https://doi.org//0.1002/pip.2427.

[23] Recamán Payo, M. et al. Opportunities for silicon epitaxy in bulk crystalline silicon photovoltaics. Proceedings of the $29^{\text {th }}$ European Photovoltaic Solar Energy Conference and Exhibition, Amsterdam (The Netherlands) 2014, 497-502. Https://doi.org/I0.4229/EUPVSEC20I420I4-2CO.I.3.

[24] Recamán Payo, M. et al. Advanced doping profiles by selective epitaxy in n-type PERT cells. Proceedings of the 30 $30^{\text {th }}$ European Photovoltaic Solar Energy Conference and Exhibition, Hamburg (Germany) 2015, 433-439. Https://doi.org//0.4229/EUPVSEC20I520I5-2CO.4.6.

[25] $\mathrm{Li}$, Y. et al. Process simplification and improvement of rear side of IBC cells by means of PECVD $\mathrm{SiO}_{x}$ and epitaxy. Proceedings of the 30th European Photovoltaic Solar Energy Conference and Exhibition, Hamburg (Germany) 2015, 466-469. Https://doi.org/I0.4229/EUPVSEC20I520I5-2DO.2.5.

[26] Kuzma-Filipek, I. et al. Integration processes for nPERT Si solar cells using single-side emitter epitaxy and front side laser doping. Energy Procedia 77 (2015) 527-533. Https://doi.org// 0.1016/j.egypro.2015.07.075.

[27] Recamán Payo, M. et al. The use of silicon epitaxy in advanced n-type PERT and IBC silicon solar cell designs. Photovoltaics International 28 (2015) 45-56.

[28] Recamán Payo, M. et al. Method for fabricating crystalline photovoltaic cells. Patent US 2016/07200I Al.

[29] Li, Y. et al. Optical and electrical performance of rear side epitaxial emitters for bifacial silicon solar cell application. Solar Energy Materials and Solar Cells 195 (2019) 43-48. Https://doi.org/10.1016/.solmat.2019.01.05I.

[30] Dang, Ch. et al. Investigation of laser ablation induced defects in crystalline silicon solar cells. Energy Procedia 55 (2014) 649-655. Https://doi.org//0.1016/j.egypro.2014.08.040.

[3I] Barbos, $\mathrm{C}$. et al. Characterization of $\mathrm{Al}_{2} \mathrm{O}_{3}$ thin films prepared by thermal ALD. Energy Procedia 55 (2015) 558-564. Https://doi.org/10.1016/j.egypro.2015.07.080.

[32] Veith, $\mathrm{B}$. et al. Comparison of the thermal stability of single $\mathrm{Al}_{2} \mathrm{O}_{3}$ layers and $\mathrm{Al}_{2} \mathrm{O}_{3} / \mathrm{SiN}_{\mathrm{x}}$ stacks for the surface passivation of silicon. Energy Procedia 8 (201I) 307-312. Https://doi.org/I0.1016/j.egypro.2011.06.14I.

[33] Dingemans, G. et al. Status and prospects of $\mathrm{Al}_{2} \mathrm{O}_{3}$-based surface passivation schemes for silicon solar cells. Journal of Vacuum Science and Technology A 30(4) (2012) 040802-1/27. Https://doi.org//0.1 I 16/1.4728205.

[34] Liu, Y. et al. Thermally induced damages of PECVD SiN ${ }_{x}$ thin films. Journal of Materials Research 26(19) (20II) 2552-2557. Https://doi.org/I0.1557/jmr.20I I.236.

[35] Russell, R. Methods for forming metal electrodes on silicon surfaces of opposite polarity. Patent WO 2016/193409 Al.

[36] Kane, D.E. et al. Measurement of the emitter saturation current by a contactless photoconductivity decay method. Conference Record of the $18^{\text {th }}$ IEEE Photovoltaics Specialists Conference, Las Vegas (USA) 1985, 578-583. 
[37] Richter, A. et al. Improved quantitative description of Auger recombination in crystalline silicon. Physical Review B 86 (2012) 165202-1//4. Https://doi.org//0.1 103/PhysRevB.86.165202.

[38] Deckers, J. et al. Injection dependent emitter saturation current density measurement under metallized areas using photoconductance decay. Proceedings of the $28^{\text {th }}$ European Photovoltaic Solar Energy Conference and Exhibition, Paris (France) 2013, 806-810. Https://doi.org//0.4229/28thEUPVSEC20132BO.2.2.

[39] Deckers, J. et al. Excess carrier density variations in test structures for photoconductance-based contact recombination current measurements. IEEE Journal of Photovoltaics 5(3) (2015) 932-937. Https://doi.org/ I0.1 109/JPHOTOV.2015.2397594.

[40] Shockley Research Laboratory. Research and investigation of inverse epitaxial UHF power transistors. Technical Documentary Report No. AL TDR 64-207, 1964.

[4I] Reeves, G.K. et al. Obtaining the specific contact resistance from transmission line model measurements. IEEE Electron Device Letters 3(5) (1 982) II I-I I3. Https://doi.org/ I0.I I09/EDL. 1982.25502.

[42] Cohen, S.S. Contact resistance and methods for its determination. Thin Solid Films 104(3-4) (1983) 36I-379. Https://doi.org/10.1016/0040-6090(83)90577-I.

[43] Schroder, D.K. Contact resistance and Schottky barriers, in: Semiconductor material and device characterization. John Wiley \& Sons, Inc., New Jersey, 2006, I27-I84. ISBN-13: 978-0-47I-73906-7.

[44] Recamán Payo, M. et al. Selective epitaxy as contact passivation approach in bifacial n-type PERT solar cells. Proceedings of the $33^{\text {rd }}$ European Solar Energy Conference and Exhibition, Amsterdam (The Netherlands 2017, 604-609. Https://doi.org/10.4229/EUPVSEC20172017-2AV.2.6.

[45] Duerinckx, F. Bulk and surface passivation of screen printed multicrystalline silicon solar cells based on plasma enhanced CVD of silicon nitride. Doctoral dissertation, KUL and imec, 1999, ISBN:90-5682-2 I0I.

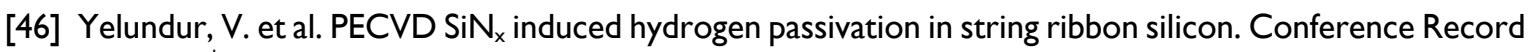
of the $28^{\text {th }}$ IEEE Photovoltaic Specialists Conference, Alaska (USA) 2000, 9I-94.

[47] Haslinger, M. et al. 'Just-clean-enough': optimization of wet chemical cleaning processes for crystalline silicon solar cells. Solid State Phenomena 255 (2016) 344-347. Https://doi.org/ 10.4028/www.scientific.net/SSP.255.344.

[48] Cuevas, A. et al. Co-optimisation of the emitter region and the metal grid of silicon solar cells. Progress in Photovoltaics: Research and Applications 8(6) (2000) 603-6/6. https://doi.org/10.1002/1099I59X(2000 I I/I2)8:6<603::AID-PIP333>3.0.CO;2-M.

[49] Cid Sánchez, M. et al. Phosphorus emitter and metal-grid optimization for homogeneous $\left(n^{+} p\right)$ and double-diffused $\left(\mathrm{n}^{++} \mathrm{n}^{+} \mathrm{p}\right)$ emitter silicon solar cells. Materials Research 12(1) (2009) 57-62. Http://dx.doi.org/I0.1590/SI5 I6-I4392009000I00006. 